\title{
Experimental Research and Finite Element Analysis on Setting Stiffening Rib of Corner Joints in Gabled Frames
}

\author{
Jin Cheng1, Zuoquan Hong², Yu Wang1 \\ ${ }^{1}$ College of Civil Engineering, Shenyang Jianzhu University, Shenyang, China \\ ${ }^{2}$ China Construction Third Bureau First Engineering Co., Ltd., Wuhan, China \\ Email: wyasyn@163.com
}

How to cite this paper: Cheng, J., Hong, Z.Q. and Wang, Y. (2016) Experimental Research and Finite Element Analysis on Setting Stiffening Rib of Corner Joints in Gabled Frames. World Journal of Engineering and Technology, 4, 15-21. http://dx.doi.org/10.4236/wjet.2016.43C003

Received: July 19, 2016

Accepted: September 19, 2016

Published: September 22, 2016

\begin{abstract}
In order to clear constructional design of corner joint, it is necessary to further investigate mechanical property of corner joint in gabled frames. Through static test and finite element software analysis of comparing the panel zone with and without inclined stiffener. Some conclusions are given in the article. The load displacement curves show that the capacity of oblique nodes installed within stiffening rib components is enhanced i.e. $40 \%$ more than those without stiffening rib nodes. The results reveal that in the gabled frames, the corner node with the inclined stiffening rib can improve the bearing capacity of the specimens. When the extraterritorial flange is tension, the erection of the inclined stiffening rib can prevent structural failure and improve effectually the ductility of the structure.
\end{abstract}

\section{Keywords}

Gabled Frame, Corner Joints, Full-Scale Experiment, Stiffening Rib, FEM

\section{Introduction}

Gabled frame structure is the most widely used structure in single industrial house and single large-span civil building at home and abroad, and the function of corner joints in gabled frame is extremely important. However, the construction of corner joints is not uniform. According to the Technical Specification for Steed Structure of Light-weight Buildings with Gabled Frames (CECS102: 2002) in (7.2.10), when the shear stress in the joint zone below the design value of shear strength of steel, stiffening rib is not necessary. But when stiffening rib is needed, a reasonable setting method is not explicitly given [1] [2]. Thus, it is necessary to further investigate mechanical property of corner 
joint in gabled frames. In this article, through full-scale experiment, some useful conclusions are given, and it also has guiding significance for practical engineering.

\section{Test Program}

\subsection{Test Specimens}

Two structural forms of corner joint in gabled frame, with and without inclined stiffening rib (Figure 1), are studied. According to the Technical Specification for Steed Structure of Light-weight Buildings with Gabled Frames (CECS102: 2002) in (6.1.1), free overhanging width-thickness ratio of compressive flange plate in I-section members should not higher than $15 \sqrt{235 / f_{y}}$; computational height-thickness ratio of web in I-section beam members and column members should not higher than $250 \sqrt{235 / f_{y}}$. $f_{y}$ is the yield strength of steel. In this experiment, steel of $\mathrm{Q}_{235}$ is used and $f_{y}=235 \mathrm{Mpa}$. Parameters Design of specimens are shown in Table 1, the overhanging width-thickness ratio of flange plate is $74.5 / 5=14.9<15$, and the height-thickness ratio of web is $640 / 3=213<250$, and all the size of specimens accord with the specification.

\subsection{Experimental Setup}

Experimental setup is shown in Figure 2.

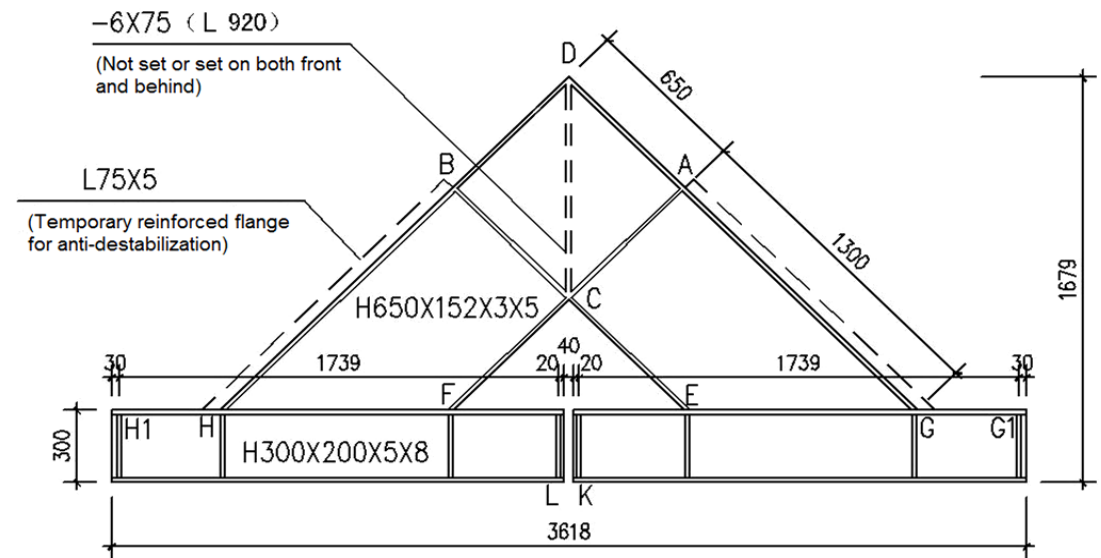

Figure 1. Corner joints specimens of gabled frames.

Table 1. Specimens parameters ( $\mathrm{mm})$.

\begin{tabular}{|c|c|c|c|c|c|c|c|c|c|c|c|c|c|c|c|}
\hline \multirow{3}{*}{$\begin{array}{l}\text { Specimens- } \\
\text { section }\end{array}$} & \multicolumn{6}{|c|}{$\begin{array}{l}\text { Specimens with inclined } \\
\text { stiffening rib }\end{array}$} & \multicolumn{9}{|c|}{$\begin{array}{l}\text { Specimens without inclined } \\
\text { stiffening rib }\end{array}$} \\
\hline & \multicolumn{3}{|c|}{ Web } & \multicolumn{3}{|c|}{ Flange } & \multicolumn{3}{|c|}{ Web } & \multicolumn{3}{|c|}{ Flange } & \multicolumn{3}{|c|}{ stiffening rib } \\
\hline & $t$ & $b$ & 1 & $t$ & $b$ & 1 & $t$ & $b$ & 1 & $t$ & $b$ & 1 & $t$ & $b$ & 1 \\
\hline Joint area & 3 & 650 & 650 & 5 & 152 & 650 & 3 & 650 & 650 & 5 & 152 & 650 & 6 & 75 & 920 \\
\hline Non-joint & 3 & 650 & 1300 & 5 & 152 & 1300 & 3 & 650 & 1300 & 5 & 152 & 1300 & - & - & - \\
\hline Arm beam & 6 & 284 & 1789 & 8 & 200 & 1789 & 6 & 284 & 1789 & 8 & 200 & 1789 & - & - & - \\
\hline
\end{tabular}

Note: $\mathrm{t}-$ thickness; $\mathrm{b}$-breadth; 1 -length. 


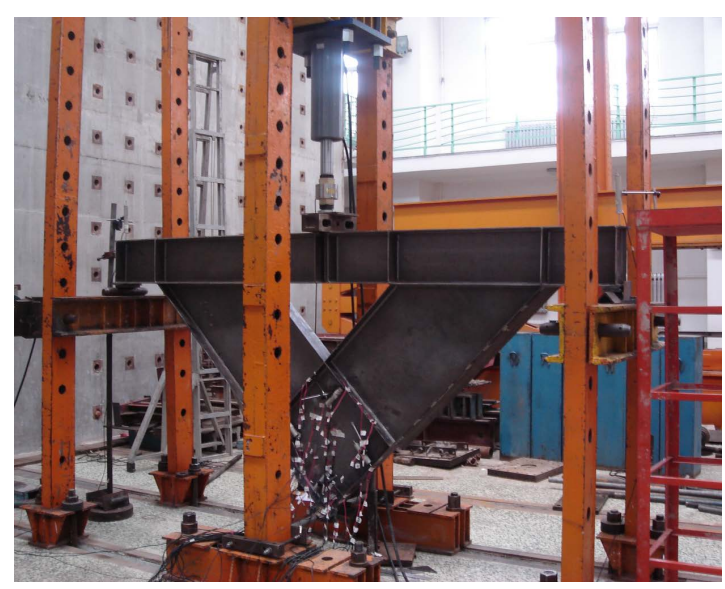

Figure 2. Experimental setup.

\subsection{Loading Conditions}

Generally, the forces received by corner joints in gabled frame are bending moments $\mathrm{M}$, shear forces V and axial forces N. Reference to national standard of Code for Design of Steel Structures (GB50017-2003) in (7.4.2), the span is large and the weight of roof is light in gabled frame. In this condition, bending moments, which contribute most forces to the joint zone, plays a decisive role; meanwhile, the influence of shear forces and axial forces can be ignored.

So this approximation will greatly simplify the trouble in load and analysis in experiment. In order to straight comparison easily, all components are used in real size in this experiment, and the section size is shown in Table 1. To ensure the accuracy of force in specimens, friction, which happens in jack and contact surface of specimens during loading, should be considered. So setting two round steel bars at force-bearing point of bottom of beam center can eliminate friction; meanwhile, distributive beam is used to make specimens' divide evenly [3] [4].

\section{Experimental Phenomena}

As Figure 3 shows, when the load of the specimen without inclined stiffening rib reaches $139.6 \mathrm{kN} \cdot \mathrm{m}$, the whole web gets the plastic stage, and wavy compressive buckling happens; stress in extraterritorial flange gradually increase and reaches ultimate strength finally with obviously buckling. All of those phenomena are not allowed in practical engineering; it is not meet the design principle of strong joint and weak member, so it is necessary to set the inclined stiffening rib to enhance the design value of strength. When the load of the specimens with inclined stiffening rib reaches 193.2 $\mathrm{kN} \cdot \mathrm{m}$, tensional buckling is happened in flange. The Figure 3 also shows that there is no obvious regularity of flange buckling and that mainly by the influence of welding residual stress of members [5] [6].

\section{Experimental Results Analysis}

The Figure 4 shows that displacement increase with load. After specimens reach the 


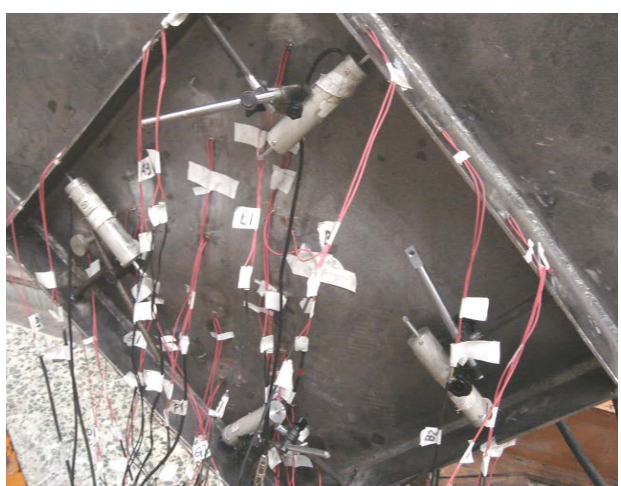

(a)

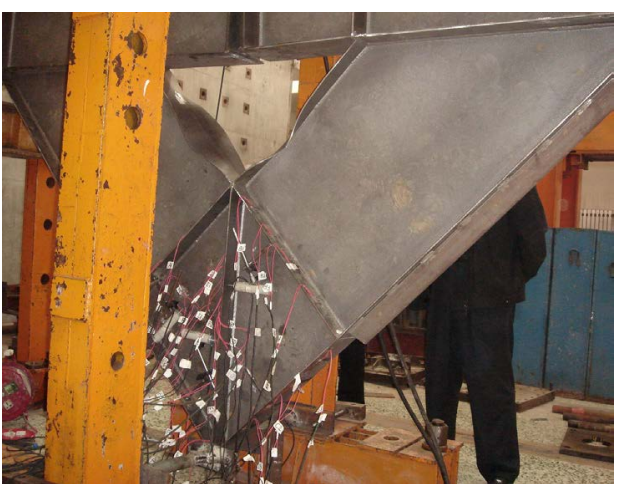

(b)

Figure 3. Failure pattern of specimens. (a) Specimen without stiffening rib; (b) specimen with stiffening rib.

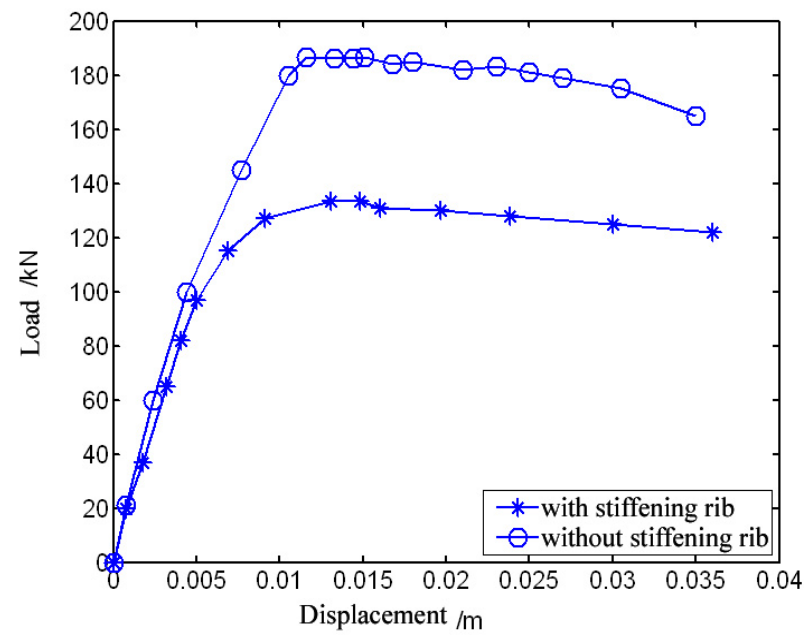

Figure 4. Curves of load displacement.

yield limit, displacement continues to increase when load decrease, and the curves change from steep to flatten. Yield strength of specimens with inclined stiffening rib is much higher than those specimens without inclined stiffening rib. This says that setting the inclined stiffening rib in corner joint zone can improve the bearing capacity greatly. As Table 2 shows, Experimental data of limit yield moment of specimens with inclined stiffening rib is more than $40 \%$ higher than those specimens without inclined stiffening rib. Therefore, the capacity of components can be improved by setting the inclined stiffening rib in corner joint zone [5]. Meanwhile, it is obvious that the specimens with inclined stiffening rib in safety storage are much higher than those specimens without inclined stiffening rib.

The structure and force of two forms of components are same in Table 2. Now the yield strength $(\mathrm{M}=193.2 \mathrm{kN} \cdot \mathrm{m})$ of components with inclined stiffening rib is viewed as the yield strength of beam-column flange of the components without inclined stiffening rib. In contrast to its failure strength $(\mathrm{M}=139.6 \mathrm{kN} \cdot \mathrm{m})$ the components will failure in joint before its connection. Reference to the Code for Seismic Design of Buildings 
Table 2. Experimental data.

\begin{tabular}{ccc}
\hline Number of specimens & Without inclined stiffening rib & With inclined stiffening rib \\
\hline Design value of bearing capacity $\left(M_{0}\right)$ & $127.6 \mathrm{kN} \cdot \mathrm{m}$ & $127.6 \mathrm{kN} \cdot \mathrm{m}$ \\
Yield bearing capacity of specimens $\left(M_{y}\right)$ & $139.6 \mathrm{kN} \cdot \mathrm{m}$ & $193.2 \mathrm{kN} \cdot \mathrm{m}$ \\
$M_{y} / M_{0}$ & 1.046 & 1.463 \\
\hline
\end{tabular}

(GB50011-2001) in (3.5.5), this is not allowed. Overall, if the construction and calculation of corner joints follow the current specification completely, under the hurricane and earthquake effect, serious problems that low strength of joint and can not meet the safety requirements will probably happen. Therefore, setting stiffening rib in the corner joint zone is feasible, and also necessary.

\section{Calculations of Finite Element and Result Analysis}

\subsection{Calculations of Finite Element}

The joints of corner are simulated and analyzed by Using ANSYS software, the unit is adopt SHELL181, which is four nodes and six degrees of freedom. Material nonlinearity and geometrical nonlinearity are considered, and BKIN is adopted. Newton-Simpson method, linear search technology and adaptive decrease are combined.

\subsection{Result Analysis of Finite Element}

In ANSYS (stress ratio, output name of ANSYS is NISRAT), the occurrence of yield is directly determined through the description of stress ratio. If a point is to yield, the stress ratio of this point will be more than or equal to 1 . When stress ratio is less than 1 , this part will be in elastic stage. Meanwhile, from the numerical size of the stress ratio it can further explain the specific circumstances of plastic development of all parts of the corner in gabled frame. As Figure 5 shows, when there is no stiffening rib, damage first appears in the web in the region of joint. It is hard to assure the design requirements of "strong joint, weak bar"; In the case of setting stiffener in the line of inside and outside corner folded point, damage first appears in the flange out of the region of joint, but there is no damage in the web in the region of joint basically. It guarantees for the design requirements of "strong joint, weak bar". So from the finite element analysis for damage maps of above three cases, we can get that setting stiffener in the line of inside and outside corner folded point is the most feasible approach [7] [8].

\section{Conclusions}

Through analysis of corner joint zone of gabled frame without stiffening rib, the formulas regulated in the Technical Specification for Steed Structure of Light-weight Buildings with Gabled Frames (CECS102: 2002) in (7.2.10) failed to involve some problems, such as web strength of joint zone, stability problems and so on. By full-scale experiment, stiffening rib should be installed in the corner joint zone for safeties propose. 


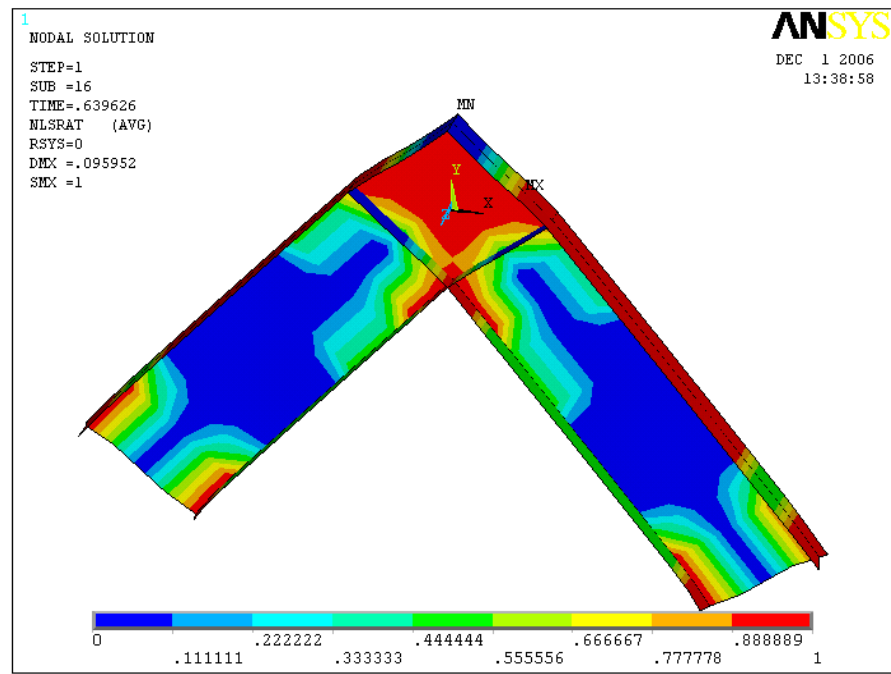

(a)

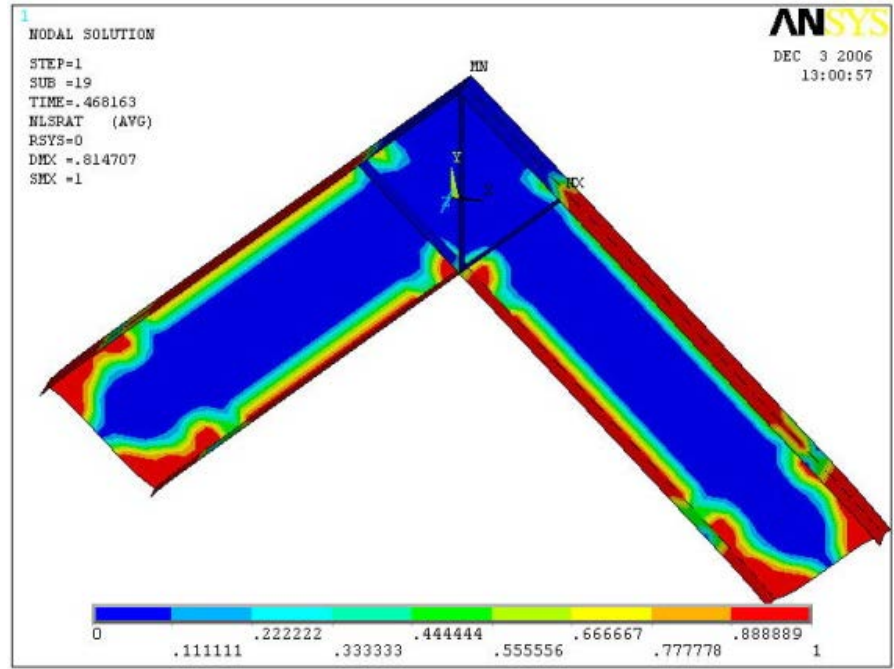

(b)

Figure 5. Finite element analysis for damage maps. (a) Component I; (b) component III.

The results show that setting stiffening rib in corner joint zone can enhance the bearing capacity of components. In practical engineering, when the extraterritorial flange is tension, the erection of the inclined stiffening rib can prevent structural failure and improve effectually the ductility of the structure.

Numerical simulation calculation results and experimental results show that the numerical simulation is an effective research tools, and simulation method can give experimental research and engineering application to bring great convenience.

\section{Acknowledgements}

The authors would like to acknowledge the financial support of Major production safety accident prevention and control of key technologies of science and technology projects (2013-10), Major production safety accident prevention and control of key 
technologies of science and technology projects (2013-12), General fund project of Shenyang Jianzhu University (2014-077).

\section{References}

[1] Wei, M.Z. (2000) Steel Structure. Wuhan Industry University Publishers.

[2] Trebilcock, P.J. (1994) Building Design Using Cold Formed Steel Sections: An Architect's Guide. The Steel Construction Institute, UK.

[3] China Association for Engineering Construction Standardization. Technical Specification for Steed Structure of Light-weight Buildings with Gabled Frames. Beijing: China Planning Press, 2011

[4] Alexander Metal: Metal Building Systems. McGraw-Hill Inc., 2012.

[5] Shi, Y.J., Liao, X.J. and Wang, Y.Q. (2005) Experimental Research on Force performance of $\Gamma$ Joints of Gabled Frames. Journal of China University of Mining and Technology, No. 3, 327-330.

[6] Wang, Y. and Liu, Y.J. (2009) Experimental Research and Finite Element Analysis on Semi-Rigid Joints of Gabled Frames. Building Science, No. 7, 21-23.

[7] Wang, Y. and Liu, Y.J. (2010) Research of Construction Design on Corner Joints of Gabled Frames. Sichuan Building Science, No. 5, 34-36.

[8] Wang, Y. and Liu, Y.J. (2008) Discussion and Finite Element Analysis on Setting Stiffing Rib for Corner Joints of Gabled Frames. Steel Construction, No. 12, 9-11.

\section{Submit or recommend next manuscript to SCIRP and we will provide best service} for you:

Accepting pre-submission inquiries through Email, Facebook, LinkedIn, Twitter, etc.

A wide selection of journals (inclusive of 9 subjects, more than 200 journals)

Providing 24-hour high-quality service

User-friendly online submission system

Fair and swift peer-review system

Efficient typesetting and proofreading procedure

Display of the result of downloads and visits, as well as the number of cited articles

Maximum dissemination of your research work

Submit your manuscript at: http://papersubmission.scirp.org/ 